\title{
Gender Differences in the Licensing and Practice of Female and Male Surgeons in Early Modern England
}

\author{
DOREEN A EVENDEN*
}

This paper will examine differences in the roles played in the practice of surgery by males and females associated with the Barber-Surgeons Company in seventeenth-century London. It will also look at the ecclesiastical licensing process as it related to the licensing of male and female surgeons. ${ }^{1}$ The evidence will show that gender differences in both the guild and ecclesiastical routes to becoming a surgeon ensured that relatively few women obtained "official" standing as surgeons in the seventeenth century. ${ }^{2}$ Moreover, although female surgeons who obtained licences might demonstrate a higher degree of empirical success than many of their male counterparts, they generally carried out their work within circumscribed limits not imposed upon male surgeons.

Aside from a substantial and motley assortment of unlicensed practitioners, a tripartite division of licensed medical practitioners provided health care in early modern England: physicians, for the most part university educated, surgeons, most commonly trained by apprenticeship, and apothecaries, also the products of apprenticeship. An informal medical hierarchy existed which placed physicians at the top of the ladder and apothecaries at the bottom, with surgeons somewhere in between. ${ }^{3}$ Although barbers, as

*Dr Doreen Evenden, Department of History, Mount Saint Vincent University, Halifax, Nova Scotia, B3M 2J6, Canada.

I wish to thank the Social Sciences and Humanities Research Council of Canada for partially funding the research for this paper. Thanks also to archivist Melanie Barber for directing me to the sources at Lambeth Palace Library relating to female surgeons, to Ian Murray for permitting access to the records of the Barber-Surgeons Company, and to Barbara Hanawalt for reading an early draft and suggesting the title.

Abbreviations: GL-Guildhall Library, London, England; LP-Lambeth Palace Library, London, England; BS-Barber-Surgeons archives, London, England. Note: In cases where transcripts were used, numbers refer to entries rather than folios.

\footnotetext{
${ }^{1}$ Feminist historians stress the importance of the comparative approach to women's history, particularly from the perspective of gender. See ch. 7, 'What is women's history . . ?', in Juliet Gardiner (ed.), What is history today?, Atlantic Highlands, NJ, Humanities Press International, 1988, pp. 82-93 passim.
}

\footnotetext{
${ }^{2}$ Although an argument could be made for the dispensability of a licence, this paper adopts the position that inclusion in the medical hierarchy brought with it tangible benefits to the licensed practitioner. See also David Harley, "'Bred up in the study of that faculty": licensed physicians in northwest England, 1660-1760', Med. Hist., 1994, 38: 398-420. Licensed physicians, regardless of their qualifications, were generally protected from harassment by rivals and church officials according to Harley.

${ }^{3}$ The tripartite division was complicated by many variations and combinations of medical practice. See below, p. 203, and Harley, op. cit., note 2 above, passim. In some instances, surgeons were able to accumulate substantial wealth. Margaret Pelling, 'Appearance and reality: barber-surgeons, the body and disease', in A L Beier and Roger Findlay, (eds), London 1500-1700, London, Longman, 1986, pp. 82-112, on p. 86. Doreen Evenden Nagy, Popular medicine in seventeenthcentury England, Bowling Green State University Popular Press, 1988, pp. 22-34. Medical practitioners were perceived as charging unreasonable fees for their services and this led to
} 


\section{Licensing and Practice of Female and Male Surgeons}

members of the Barber-Surgeons Company, have frequently been credited with performing a full range of surgical tasks, in London they were restricted to blood-letting. Phlebotomy was frequently employed in the treatment and prevention of a whole host of disorders but did not confer upon its practitioners recognition as part of the "official" medical establishment. This distinction between barbery and surgery is a critical one, particularly when investigating the role of women. Although in many cases, the care afforded by unlicensed practitioners was as effective as that provided by licensed medical personnel, this is not the primary concern of this paper. ${ }^{4}$ The present investigation revolves around the requirements for obtaining a surgeon's licence and whether gender played a role in shaping those requirements.

\section{Distinctions between Barbers and Surgeons}

The names of English women who engaged in the unlicensed practice of "physick" and surgery in the early modern period appear as scattered references in diaries, letters and official records. When we turn to the question of female licensed practice, the traces become fainter. This study attempts to clarify the situation with regard to female surgeons, particularly those who practised in and about London in the seventeenth century. This is achieved by an examination of existing records of the two licensing agencies of the period: the Barber-Surgeons Company of London and the Church.

Most studies of English medical practitioners have yielded very little information about women who practised as licensed physicians or surgeons in the seventeenth century. This is because women generally carried out their work without the official sanction of a licence. In the case of female physicians, only two were named in a study of early seventeenth-century provincial licensed medical practice. ${ }^{5}$ A study of ecclesiastically licensed physicians and surgeons in the diocese of London similarly failed to yield the names of any women who were licensed by the Church in either medical or surgical practice. $^{6}$

In the case of London female surgeons, it has generally been accepted that women were able to enter the profession of surgery by way of an apprenticeship with a member of the Barber-Surgeons Company, without experiencing any restriction on either their entry or their practice after successfully meeting all the Company's requirements after apprenticeship. This view was based on the work of Sidney Young whose Annals of the Barber-Surgeons of London, drawn from Company records and published just over a

\footnotetext{
numerous calls for reform, especially in the civil war period. Despite their ranking in the informal hierarchy, and a dearth of information about practitioners' incomes generally, apothecaries' incomes were, based on available evidence, higher than surgeons'. For a comment on the social status of apothecaries see Margaret Pelling, 'Knowledge common and acquired: the education of unlicensed medical practitioners in early modern London', in Vivian Nutton and Roy Porter (eds), The history of medical education in Britain, Amsterdam, Rodopi, 1995, pp. 259-60.

${ }^{4}$ Pelling, op. cit., note 3 above, pp. 250-79.
}

\footnotetext{
5 John H Raach, A directory of English country physicians 1603-1643, London, Dawsons of Pall Mall, 1962, and idem, 'English medical licensing in the early seventeenth century', Yale J. Biol. Med., 1949, 16: $267-88$, on p. 283 . One of the two provincial female practitioners was licensed to practise in the dioceses of Lincoln, Ely, and London but not in the City or within seven miles.

6 J Harvey Bloom, R Rutson James, Medical practitioners in the Diocese of London, licensed under the act of 3 Henry VIII, C.11; an annotated list 1529-1725, Cambridge University Press, 1935.
} 
century ago, remains the single most valuable published source on the topic. ${ }^{7}$ Young's contention was in the main correct; women were admitted to membership in the Company by apprenticeship and patrimony (as the daughters of Company members), thereby enjoying all the same privileges as any freeman except wearing the livery. ${ }^{8}$ What Young failed to do was to distinguish between female Company members who were barbers and those who were surgeons; hence we are given no specific examples of women who were both members of the Barber-Surgeons Company and practising surgeons. ${ }^{9}$ The most recent study of English female surgeons has accepted Young's observations on the presence of women in the London Barber-Surgeons Company. ${ }^{10}$ By comparing the London registers of apprenticeship bindings (the records of apprentices who were "bound" by legal agreement for a specific number of years to serve a member of the Company) with the registers of freedom (the lists of those who had successfully completed their apprenticeships and now enjoyed all the rights and privileges of the Company) the conclusion emerges that few seventeenth-century women, if any, were permitted to practise surgery by right of apprenticeship, patrimony, or as widows of freemen surgeons of the Company. ${ }^{11}$ The distinction between membership in the Company as a barber or surgeon is not easily established since recording practices were not uniform. In some cases it is necessary to trace apprentices and masters back for many generations in the records of apprenticeship bindings and/or admissions to freedom before finding the " $b$ " or "chir" (for chirurgeon) which distinguished the barber from the surgeon; in many cases, the designation cannot be found. ${ }^{12}$ There is no dearth of girls and women who were bound to learn the craft or trade of barbers; the difficulty arises when the focus of the investigation becomes women who may have aspired to the more prestigious

\footnotetext{
${ }^{7}$ Sidney Young, Annals of the Barber-Surgeons of London, London, Blades, East and Blades, 1890. For a comparison with the barber-surgeons of York see Margaret C Barnet, 'The barber-surgeons of York', Med. Hist., 1968, 12: 19-30. The York records refer to one woman who practised surgery in 1572 , evidently with the company's permission and evidence of continued "good behaviour" (p. 27). Joan Lane's study of provincial medical apprentices and practitioners contains no names of females. Joan Lane, 'Provincial medical apprentices and masters in early modern England', Eighteenth-Century Life, 1988, 12: 14-27.

8 Young, op. cit., note 7 above, p. 260.

${ }^{9}$ Young also failed to distinguish between those who practised barbery or surgery and those who were free of the Company, but were engaged in other crafts and trades, particularly instrument making, which may have been directly related to surgeons' tools. GL MS 5266A (unfol.) Oct. 13, 1659, Dec. 20, 1664, Feb. 14, 1664, Dec. 7, 1669, April 6, 1669 , Oct. 17, 1671. See Alice Clark, Working life of women in the seventeenth century, London, Routledge \& Kegan Paul, 1982, pp. 176-7.

${ }^{10}$ A L Wyman, 'The surgeoness', Med. Hist., 1984, 28: 22-41, p. 26. For similar acceptance see
}

\begin{abstract}
Margaret Pelling and Charles Webster, 'Medical practitioners', in Charles Webster (ed.), Health, medicine, and mortality in the sixteenth century, Cambridge University Press, 1979, pp. 165-235, on p. 174. Diane Willen's study of York Guildswomen has not distinguished between female barbers and surgeons. Diane Willen, 'Guildswomen in the city of York, 1560-1700', The Historian, 1984, 43: 204-28, p. 217.

${ }^{11}$ Not only was the apprentice, who wished to learn the craft or trade, legally obligated to serve the Company member, the employer was also obligated or "bound" to instruct him or her. The only woman who I was able to establish as having been apprenticed to a surgeon was Mary Jollard, daughter of a gentleman from Lincoln, who was bound to a surgeon in 1691. There is no other mention of her, indicating that she did not complete her apprenticeship. GL MS 5274/2/312.

12 For example, the records of apprenticeship bindings between 1600 and 1635 distinguish between those admitted by service or patrimony but provide no indication whether the practice was in surgery or barbery. After 1635 there is sporadic indication of status differentiation which shows that female barbers bound apprentices.
\end{abstract}




\section{Licensing and Practice of Female and Male Surgeons}

profession of surgery by apprenticeship with a surgeon who was a Company member. ${ }^{13}$ Young gives us only two examples of women who were Company members and both examples relate to the binding of apprentices. Daniel Alderson, son of the deceased barber-surgeon James Alderson was apprenticed to his mother Katherine Alderson, but no evidence has been found that the senior Aldersons were surgeons and not barbers. ${ }^{14}$ Young's second example, that of Katharina Bowghy, bound to barber-surgeon William Bennett and his wife, has also proven elusive; Bowghy's name does not appear in the registers of freedom; we suspect the Bennetts were barbers, not surgeons. ${ }^{15}$

Although the distinction between barber and surgeon has been obscured in the surviving records, at the time of union between the Barber-Surgeons Company and the Fellowship of Surgeons in 1540, it was clear that a separation of duties and responsibilities was intended. Certain benefits as well as qualifications were attributed to surgeons and not to barbers. ${ }^{16}$ The Company charter had made provision for the annual election of two barbers and two surgeons as Master and Wardens. When this practice was found inconvenient and contentious, on two occasions Charles I was compelled to send a mandate to the Company which directed that two surgeons must be included because "the lives and safetie of our people are so much concerned ..." and that any freeman of the Company "following any profession than that of Barber or Surgeon should be taken as a Barber". ${ }^{17}$ In equating barbers with other tradesmen who were freemen of the Company, royal authority was clearly making the separation between the two arms of the Company. Surgeons were seen as part of the medical establishment, the ubiquitous barber was viewed in some quarters as a purveyor of services, one step removed from a domestic servant. ${ }^{18}$ In addition, surgeons were not to practise barbery while barbers were forbidden the practice of surgery but were permitted to extract teeth. ${ }^{19}$

Despite casual record-keeping, in the following century, the Company members themselves were very much aware of the distinction. In 1645 Henry Cantrell complained to the Company court that another member (obviously a surgeon) had insulted him calling him a "quack salver", newly arrived from "rubbing the horseheels and but a barber". ${ }^{20}$ In

\footnotetext{
${ }^{13}$ Margaret Pelling has noted the "feminized" role of the barber. Margaret Pelling, "Compromised by gender: the role of the male medical practitioner in early modern England', in Hilary Marland and Margaret Pelling (eds), The task of healing: medicine, religion and gender in England and the Netherlands, 1450-1800, Rotterdam, Erasmus Publishing, 1996, pp. 101-33, p. 117. For examples of women who were bound as barbers see GL MS 5266A (unfol.) Sept. 5 , 1667 (Lucy Vaughan), June 1, 1670, (Ann Wood).

14 Young, op. cit., note 7 above, p. 270.

15 Ibid., p. 270. Part of the difficulty in this case arises from the name "William Bennett", which was very common. In addition, in some cases, women's names appear in the records of apprenticeship bindings but not in the registers of freedom. This is not surprising in view of the high "dropout" rate among apprentices overall: in the years 1603-1674 of an average of 133 apprentices "presented" annually, only 48 were admitted to freedom. Young, op. cit., note 7 above, p. 259 .
}

\footnotetext{
16 Jessie Dobson and R Milnes Walker, Barbers and barber-surgeons of London, London, Blackwell Scientific Publications for the Worshipful Company of Barbers, 1979, p. 34.

17 Young, op. cit., note 7 above, pp. 339-40.

18 Peter Earle, A city full of people, London, Methuen, 1994, pp. 85, 206, 218.

19 Young, op. cit., note 7 above, p. 8. Young notes an exceptional case in 1557 when William Thomlyn was admitted to the Company and given permission to "drawe teeth and to make cleane teethe and no more" (p. 178). In 1597, four freemen of the Company were reported for practising barbery and surgery but the Company chose not to press charges (p. 189). London differs from Norwich in this respect. See Margaret Pelling, 'Occupational diversity: barbersurgeons and the trades of Norwich, 1550-1640', Bull. Hist. Med., 1982, 56: 484-511, p. 503.

${ }^{20}$ GL MS 5257/5/351.
} 


\section{Doreen A Evenden}

the same year, barber Thomas Shaw was denied the right to apprentice Henry Blekisopp as a surgeon because Shaw lacked certain qualifications, including the right to attend anatomy lectures. ${ }^{21}$ Evidence from the City of London Mayor's Court interrogatories also supports the view that members of the Barber-Surgeons Company practised as barbers or surgeons, but lacked the Company's sanction to practise as both. ${ }^{22}$ The reality of this separation might break down when put to the test of day-to-day living, but the letter of the law, it can be argued, could be conveniently invoked to exclude women from surgical practice and ensure that they would be confined to their "proper" sphere of barbery. ${ }^{23}$

Moreover, in the early modern period, Jonathan Sawday has argued that women's bodies became the target of the male surgeons' most aggressive anatomizing activities as they sought to understand and, hence, control the inherent threat lurking in female reproductive capacity. ${ }^{24}$ In such a context women's attendance at the "anatomies" or dissections held periodically by the Barber-Surgeons Company for purposes of instruction would have been unthinkable. ${ }^{25}$ In addition to the difficulties presented by the rigid code of modesty which pervaded the period, Margaret Pelling has demonstrated that surgery was seen as the most "masculine" of the three divisions of medical practice. As a result, women would be considered less suited to surgical practice than to the more feminized occupations of physician and apothecary. ${ }^{26}$

\section{Literacy and Education}

Any explanation of the exclusion of females from an apprenticeship leading to membership in the Barber-Surgeons Company must take into account the language/literacy requirement. Although the 1556 requirement for a candidate in surgery to read and write Latin "sufficiently" was repealed in 1557 , and only the ability to "at

${ }^{21}$ GL MS 5257/5/353. At the time of union, legislation provided for the surgeons to have the bodies of four executed criminals annually to be used for anatomy demonstrations and accompanying lectures. All surgeons who were Company members were expected to attend. See Dobson and Walker, op. cit., note 16 above, pp. 34,45 .

22 See the case of Oliver $v s$. Bray in Thomas $\mathrm{R}$ Forbes, 'Apprentices in trouble: some problems in the training of surgeons and apothecaries in seventeenth century London', Yale J. Biol. Med., 1979, 52: 227-37, pp. 235-6. R S Roberts has commented on instances where surgeons trespassed into the realm of the barber and the resulting prosecutions, particularly in the first two decades of the seventeenth century. R S Roberts, 'The personnel and practice of medicine in Tudor and Stuart England, Part II, London', Med. Hist., 1962, 6: 217-34, pp. 225-6.

${ }^{23}$ Women who aspired to be surgeons could be excluded on the basis of their (perceived) innate inferiority as well as by the traditions, laws, and beliefs of the English Renaissance. According to Betty S Travitsky, the patriarchal and hierarchical mindset of the English Renaissance brought a shrinking sphere of activity for women which extended to the professions. Anne M Haselkorn, Betty S Travistky (eds), The Renaissance

Englishwoman in print: counterbalancing the canon, Amherst, University of Massachusetts Press, 1990, p. 12. While not "professionalized" in the twentiethcentury sense, surgeons, as possessors of a particular body of knowledge could be considered "professionals".

24 Jonathan Sawday, The body emblazoned: dissection and the human body in Renaissance culture, London, Routledge, 1994, pp. 9, 10, 183-229 passim.

25 Ibid., pp. 230, 242. Margaret Cavendish, Duchess of Newcastle, regretted not having seen a dissection but evidently accepted the gender barriers erected around the dissecting theatres by the surgeons which have been seen as part of the "masculinization" of science. Not only were female writers of the period careful to assert their personal "modesty", but women's excessive modesty was seen, in some cases, as contributing to a denial of sound medical care. Elaine Hobby, Virtue of necessity: English women's writing 1649-88, Ann Arbor, University of Michigan Press, 1989, pp. 9, 181; Evenden Nagy, op. cit., note 3 above, pp. 71-3.

${ }^{26}$ Pelling, op. cit., note 13 above, p. 117 . 
least" read and write was necessary, the Company's new charter in 1629 once again made it mandatory for apprentices to "readily construe Latin". ${ }^{27}$ Barber-Surgeons' records for 1648 show that the Company's court forbade surgeon Robert Morley from binding a prospective apprentice because he could only read Latin but "not make any construction thereof", therefore rendering him incapable of becoming a surgeon's apprentice "according to ordinance". ${ }^{28}$ In her study of provincial medical apprentices, Joan Lane has noted the impossibility of apothecaries' or surgeons' apprentices dealing with "bills, prescriptions and other evidence that remains" without a knowledge of Latin. ${ }^{29}$ According to Young, as late as 1727 surgeons' apprentices found it necessary to command a working knowledge of Latin. ${ }^{30}$ A collection of anatomy lectures delivered at Gresham College by Thomas Winston, Fellow of the College of Physicians, was peppered with Latin terminology directed at an audience with a knowledge of the classics. ${ }^{31}$ The requirement regarding Latin would virtually preclude any opportunity of a surgeon's apprenticeship for all but the handful of leisured women, blessed with the opportunity of private instruction in the classics by private tutors (or a well-educated parent), who would, in any case, be unlikely to seek their living as surgeons. ${ }^{32}$ Barred from universities, the majority of women were also excluded from grammar schools and their classical curriculum. ${ }^{33}$

27 Young, op. cit., note 7 above, pp. 309, 312; BS Trans. 5257/1/13; G Parker, The early history of surgery in Great Britain, London, A \& C Black, 1920 , p. 119. The requirement for proficiency in Latin must have been seen as an unrealistic one in some quarters since the dedication of an anatomy book published in English in 1553 noted that it was for the benefit of "unlatined surgeons" and that it would benefit, ultimately, a much greater number of individuals than a treatise in Latin. See Dobson and Walker, op. cit., note 16 above, p. 39. One hundred years later a translation of a treatise by John Pecquet, New anatomical experiments of John Pecquet of Deip, London, 1653, voiced a similar concern, noting that it was "for the benefit of those whose Latine is weaker than their Hands". The re-imposition of the requirement may have been linked to the fact that the Royal College of Physicians granted surgeons the right to "practise medicine as far as it was required in surgical cases" in 1627. See Roberts, op. cit., note 22 above, p. 226 . In the late sixteenth century the ambivalence of surgeons regarding the requirement for Latin was reflected in the will of Robert Balthrop, two of whose three apprentices spoke Latin and who bequeathed to the Company Latin treatises as well as his own English translations for his "bretheren practisinge Chiurgerie and not understandinge the latin Tounge ... for theire Dayly use and Readinge both in lattin and Englishe", Young, op. cit., note 7 above, p. 354. For the requirement of Latinity and the London College of Physicians, see Pelling, 'Knowledge common and acquired', op. cit., note 3 above, pp. 251, 267.

28 GL MS 5257/5/427.

${ }^{29}$ Lane, op. cit., note 7 above, p. 19.

30 Young, op. cit., note 7 above, p. 354.
${ }^{31}$ Dr Thomas Winston, Anatomy lectures at
Gresham Colledge, London, 1659.
${ }^{32}$ Suzanne W Hull has noted that girls were generally excluded from the grammar schools where Latin was taught to boys in the early seventeenth century. Suzanne W Hull, Chaste, silent and obedient: English books for women 1475-1640, San Marino, Huntington Library, 1982, pp. 3, 25-6. See also Hobby, op. cit., note 25 above, p. 192 , on this point. In the years $1640-60$, the majority of medical treatises directed to licensed medical practitioners (physicians and surgeons) were, however, printed in English, making them available to literate women. Evenden Nagy, op. cit., note 3 above, pp. 45-6.

33 Walter Ong has argued that women were excluded from the "Latin world" of the humanist educators. He notes that Sir Thomas More and a few other humanists advocated the teaching of Latin to girls in the home, an approach which was generally unsuccessful, and that up to the present, Latin has never held the same importance in female educational institutions as in those educating boys. Walter J Ong, 'Latin language study as a Renaissance puberty rite', Studies in Philology, 1959, 56: 103-24, pp. 110-11. See also Anthony Fletcher, Gender, sex and subordination in England 1500-1800, New Haven, Yale University Press, 1995, ch. 18, 'Educating girls', pp. 364-75. Susan Groag Bell has suggested that women who wanted to enter the professions in the Renaissance period were handicapped by their inability to acquire a knowledge of Latin. Susan Groag Bell, 'Medieval women book owners: arbiters of lay piety and ambassadors of culture', in Mary Erler and Maryanne Kowaleski (eds), Women and power in the Middle Ages, Athens, Ga., University of Georgia 


\section{Doreen A Evenden}

At the end of the seventeenth century women themselves were still acutely aware of the limitations placed on them by their education although they questioned the view that an individual should be "thought Unlearned for want of those two [classical] languages". 34 One early eighteenth-century writer in the Female Tatler bemoaned the fact that women who understood Latin were considered guilty of "petty treason". ${ }^{35}$ Although at certain junctures authorities might have found it unrealistic to bar promising male candidates who lacked facility in Latin, it would be a convenient rule to invoke against a female candidate adjudged mentally and physically, as well as morally and spiritually, inferior by a medical profession still heavily influenced by the teaching of the ancients. ${ }^{36}$

As evidence of a general literacy requirement for surgeons, court minute books note that in 1640 "Doctor" Livesay of Deptford was required to produce his licence, issued at an earlier date by the Bishop of Rochester, because of complaints that he was unable to read. ${ }^{37} \mathrm{~A}$ treatise by the sixteenth-century royal surgeon Thomas Vicary, which was reprinted throughout the seventeenth century, notes that a surgeon should be well educated, have an inquiring mind, and good hands. ${ }^{38}$ Surgeon Richard Banister railed against "the boldness of many women, who for lack of learning, cannot be acquainted with the Theoricke part and yet dare venture on the Practicke". 39 Studies of female literacy have estimated that early in the seventeenth century, fully 85 per cent of London women would be considered illiterate, while toward the end of the century, about 50 per cent

Press, 1988, p. 166. For examples of well-educated women of the aristocracy and upper class who were familiar with, and in some cases translators of, the classics: Elaine V Beilin, Redeeming Eve: women writers of the Renaissance, Princeton University Press, 1987; Daniel R Woolf, 'A feminine past: women and history in early modern England', 1994, unpublished paper. In commenting on the formidable obstacles which female writers had to overcome, Louise Schleiner has noted the "meagerness of usual female education even among aristocrats" in her recent study Tudor and Stuart women writers, Bloomington, Indiana University Press, 1994, p. 2. The expectation that surgeons should have a knowledge of Latin was not unique to the English experience in the sixteenth and seventeenth centuries. Wyman has noted that in fourteenth-century Italy, two women were granted surgeon's licences because of their competence and despite the fact (as the licensing authorities were careful to note) that they knew no Latin. Wyman, op. cit., note 10 above, p. 24.

${ }^{34}$ See An essay in defence of the female sex (1696), in Vivien Jones (ed.), Women in the eighteenth century, London and New York, Routledge, 1990, pp. 211-13.

35 Woolf, op. cit., note 33 above, p. 14 .

${ }^{36}$ For an example of a particularly vitriolic attack by a physician on women's inherent deficiencies as well as those imposed by their lack of formal education see John Cotta, A short discoverie ... (1612), in Evenden Nagy, op. cit., note 3 above, pp. $71-2$. Nor were these ideas unique to the medical profession. See Robert Michel, 'English attitudes towards women', Canadian J. Hist., 1978, 13 (1): 35-60 passim. Michel points out the enduring influence of the theories of Hippocrates, Aristotle, and Galen regarding women's inherent bodily and mental weaknesses which placed them in an inferior position to men. According to Suzanne Hull's study of books for Englishwomen which covered the years 1475-1640, women were bombarded with maleauthored prescriptive literature emphasizing women's inferior and subservient status and the need for male instruction on everything from domestic duties to personal conduct. Hull, op. cit., note 32 above, p. 134. See also Fletcher, op. cit., note 33 above, ch. 4, 'The weaker vessel', pp. 60-82. Vern Bullogh's pioneering work on the medieval period indicts the church as well as the ancients in the formation of enduring perceptions of women. Vern Bullough, 'Medieval and scientific views of women', Viator, 1973, 4: 484-501.

${ }^{37}$ GL MS 5257/5/261.

38 Thomas Vicary, The Englishman's treasure with the true anatomie of man's body, 9th ed., London, 1641, pp. 3-5. There were also traditional perceptions of somewhat different requisite qualities relating to the surgeon's courage, eyesight, and again, the hands, which should be like a lady's. Pelling, op. cit., note 13 above, p. 117.

${ }^{39}$ Richard Banister, A treatise of one hundred and thirteene diseases of the eyes, and eye liddes, London, 1622. 


\section{Licensing and Practice of Female and Male Surgeons}

lacked the basic skills required for literacy. ${ }^{40}$ It is apparent that the rules requiring Latin were not firmly in place throughout the century, but even during the short periods of time which saw them lifted or lapsed, the barrier of a basic literacy requirement would prove insurmountable for substantial numbers of the female population, some of whom might otherwise have aspired to become surgeons and freewomen of the Barber-Surgeons Company. Educational barriers existed which prevented women from attaining this goal and gender was not only inextricable from these barriers, it was also key to women's exclusion from the medical hierarchy. ${ }^{41}$

\section{Widows of Company Members}

Evidence from the records of the Barber-Surgeons themselves further demonstrates the difficulties faced by women who wished to carry on the profession of surgery. Many guilds or companies, as they later became known, permitted the widows of members to carry on the work of their deceased husbands. ${ }^{42}$ Court records of the Barber-Surgeons for the year 1613 note the following order:

such widows as have been Master's wives and do keep shop or bind apprentices shall pay their quarterage [dues] but for such as do neither keep shop nor bind apprentices they shall not pay any quarterage and yet notwithstanding they shall be bidden to the feast yearly. ${ }^{43}$

The question remains, however, as to how many masters' widows were widows of surgeons who were carrying on their husbands' craft? For widows of barbers, surviving evidence supports the view that for most of the century, they were permitted to carry on their husbands' work. In 1607 the newly widowed Mistress Burrows was given permission to keep her barber's shop open for two years, providing that she did not marry a husband of another trade within that time. Other widows engaged in barbery throughout the century. ${ }^{44}$ In 1609 a widow was reprimanded for keeping "two shops of barbing without Bishopsgate". 45 To mention but two of the many widows of barbers who bound male and female apprentices, the records for 1665, 1668 and 1669 show that Mary Newman and Katherine Brownell, both barbers' widows, bound apprentices for the customary seven years. ${ }^{46}$

In the case of surgeons' widows, however, examples from the first half of the century, in particular, suggest that they were not permitted to carry on the practice of surgery and were forced to release apprentices who had been bound to their husbands. Court minutes for 1607 show that surgeon's widow Eaton's apprentice Waite was bound over to Ronald Daynty for the remainder of his unexpired term. ${ }^{47}$ The widow of surgeon Browne was similarly ordered to turn over her apprentice to Thomas Thorney "to serve the residue of his term" in 1609, while almost fifty years later, surgeon's widow Susan Loveday turned over her apprentice Samuel Moulton to surgeon Robert Trott. ${ }^{48}$ In 1641, even though

\footnotetext{
${ }^{40}$ David Cressy, Literacy and the social order, Cambridge University Press, 1979, p. 145.

${ }^{41}$ Harley, op. cit., note 2 above, p. 398.

42 For a full discussion of this point see Clark, op.

cit., note 9 above, ch. 5, 'Crafts and trades' passim.

43 BS Trans. 5257/4/783.

44 BS Trans. 5257/4/24.
}

45 BS Trans. 5257/4/4 Sept. 15, 1607. According to the bylaws of 1606 , no barber could use more than one shop. Young, op. cit., note 7 above, p. 119.

46 GL MS 5266A May 9, 1665, March 2, 1669, July 16, 1668. Brownell bound two apprentices.

47 BS Trans. 5257/4/18.

48 GL MSS 5257/4/394, 5266A Dec. 1, 1658. 


\section{Doreen A Evenden}

George Boydell was described as "their apprentice", Mistress Foster, widow of surgeon Francis Foster, had to refund part of his premium, see that he was decently clothed and turn him over to surgeon Thomas Allen for the balance of his apprenticeship. ${ }^{49}$ Although not widowed, Brigid Harris, whose husband Ralph was a surgeon with the East India Company, was compelled to transfer their apprentice Richard Venner "to any man of this [barber-surgeons'] company" in 1617 "for that she is not able to teach him his trade". 50 Some years later, in 1646, the wife of surgeon John Dawes "absent at sea and believed dead" consented to her apprentice serving the remainder of his term under surgeon John Kendall. $^{51}$

Although widows of surgeons may have carried on their husbands' practices with the blessing of the Company, to date no evidence has been recovered that demonstrates that this was the case, particularly when apprentices were involved. Surviving evidence points instead to a Company policy which viewed as unacceptable a woman's long-term supervision of apprentices in surgery which resulted from the absence or death of a spouse. In many crafts and trades, wives were intimately involved with their husbands' work and the training of apprentices which was carried on in the home setting. Similarly, there is every reason to believe that many surgeons' wives acted as assistants thereby becoming familiar with all aspects of their husbands' practice. ${ }^{52}$ Gender bias appears to have played a role in the exclusion of surgeons' widows from the rights and privileges traditionally accorded widows of Company members. ${ }^{53}$

\section{Licensing of Male Practitioners}

In 1511 Parliament passed legislation enabling the Church to grant licences for the practice of medicine and surgery. As part of the licensing process, an unspecified number of "expert persons" were to examine the candidates and provide testimonial letters attesting to their competence. ${ }^{54}$ None of these testimonials have survived for the early part of the century for the City of London, although John Raach has found a single surviving

49 GL MS 5257/1/287.

50 BS Trans. 5257/4/1034.

51 GL MS 5257/1/5/356.

52 The wife of Kent surgeon John Causabon assisted him in his practice. Richard Hunter and Ida MacAlpine, 'The diary of John Causabon', Proceedings of the Huguenot Society of London, 1966, 21: 31-57, p. 37. Numerous diaries and letters from the period contain descriptions of, and references to, females who, without the benefit of a close association with a surgeon, successfully carried out surgical procedures. These women, like countless others, demonstrated that females lacked neither the necessary courage nor the skill to perform as surgeons. For examples of unlicensed female surgical practice see Evenden Nagy, op. cit., note 3 above, pp. 54-78 passim; Lucinda Beier, Sufferers and healers: the experience of illness in seventeenthcentury England, London, Routledge and Kegan Paul, 1987, p. 223.

\footnotetext{
53 The records of the company do not support the view that women were not permitted to practise surgery because of actual negligence or malpractice: their threat was more perceived than actual. Four women were fined for practising surgery between 1606 and 1640 , but there is no indication of whether they were Company members or whether actual negligence was involved. Young, op. cit., note 7 above, p. 392; BS Trans. 5257/4/468, 496; GL MS $5257 / 5 / 265$. There are on the other hand examples of malpractice among (male) Company members which resulted in the death of the patient. See GL MS 5257/5/331, 345.

54 For an exhaustive discussion of the process as it applied to midwifery candidates see Doreen Evenden-Nagy, 'Seventeenth-century London midwives: their training, licensing and social profile', PhD dissertation, McMaster University, 1991.
} 
testimonial from 1603 in the diocese of Lincoln. ${ }^{55}$ Among the most insightful comments on surgeons practising in the second half of the seventeenth century, however, are the testimonials presented to the ecclesiastical courts of the Bishop of London and the Archbishop of Canterbury. Seventeenth-century testimonials survive for nearly one hundred surgeons and the dozen or so practitioners designated as "doctors and surgeons" who were licensed by the Bishop of London; similar evidence has survived for thirteen surgeons and forty-one physician-surgeons who were issued Lambeth licences. ${ }^{56}$ Included among these are the credentials of a handful of female candidates who sought a licence to practise surgery. Before turning to these, the documents relating to the training and licensing of male licensees warrant examination. ${ }^{57}$

Although the Act of 1511 had made the Bishop of London and the Dean of St Paul's responsible for examining and licensing surgeons, at the time of union in 1540 it was agreed that the Bishop would not grant a licence until the candidate in surgery had been examined and approved by the Company. In 1599 the Company complained to the Bishop because licences were being issued to candidates without the requisite examination and approval. ${ }^{58}$ By 1660 , while a number of surgeons seeking ecclesiastical licences were freemen in good standing with the Barber-Surgeons Company, there were also candidates appearing in the ecclesiastical courts who had no previous association with the Company. ${ }^{59}$ All told, approximately one-third of the men who were licensed in surgery by the Bishop of London referred to their connections with the Barber-Surgeons Company, although not all were Company freemen. ${ }^{60}$

\footnotetext{
55 Raach, Directory, op. cit., note 5 above, p. 279. Raach has uncovered only one female, Katherine Greene of Royston, Hertfordshire, who was licensed in physic in 1626 (p. 283).

56 Joan Lane has noted that the category of physician and surgeon would be replaced by the surgeon-apothecary in the eighteenth century, the latter forming the majority of medical practitioners in the provinces by 1783 . See Joan Lane, 'The medical practitioners of provincial England in 1783', Med. Hist., 1984, 28: 353-71 passim. David Harley, however, has argued for a more sophisticated classification of medical practitioners which would lessen the importance of the surgeon-apothecary in the development of the general practitioner. Harley, op. cit., note 2 above, p. 419 .

57 The testimonial certificates from the Bishop of London's court cover the years 1661-1700 while the Lambeth records from the Archbishop of Canterbury's court are from roughly the last decade of the century.

58 Dobson and Walker, op. cit., note 16 above, p. 46. Since to practise in London one had to have the freedom of the city, surgeons who had apprenticed with Company members were spared the very substantial levy imposed on surgeons with only an ecclesiastical licence, who had to purchase their freedom. See Parker, op. cit., note 27 above, p. 87.

59 John Deavenish of St Lawrence Jewry and William Layfield (who had served the company in its
}

top administrative positions), had served their apprenticeships with members of the Barber-Surgeons Company and were freemen of the company, GL MSS 10,116/1,3. A study of practitioners licensed to practise in the diocese of London has acknowledged the friction between the two licensing bodies but contended that the bulk of the ecclesiastical licences were granted to men who were already members of the Barber-Surgeons Company. See Bloom and James, op. cit., note 6 above, p. 8. There is evidence that in Bristol, also, the Church was pre-empting the role of the Barber-Surgeons Company. In this case the Bishop declared the licence issued by the BarberSurgeons invalid unless accompanied by an ecclesiastical licence. See Parker, op. cit., note 27 above, p. 86; Harley and Guy also note the problems between the bishop and the Barber-Surgeons Company in Bristol, Harley, op. cit., note 2 above, p. 399; John R Guy, 'The episcopal licensing of physicians, surgeons and midwives', Bull. Hist. Med., 1982, 56: 528-42, p. 533.

60 In some cases candidates overtly referred to their status as freemen, in others, they referred to their examinations by the masters at Barber-Surgeons Hall. None of the surgeons licensed by the Archbishop of Canterbury in the closing decade of the century claimed membership in the BarberSurgeons Company but Thomas Nevett, citizen of London and barber-surgeon, was licensed in 1698 as a physician and surgeon. LP VX 1A/10/308. 


\section{Doreen A Evenden}

Ecclesiastical authorities were clearly prepared to accept other evidence of a practitioner's expertise in surgery aside from, or in addition to, being bound as an apprentice at Barber-Surgeons Hall or serving a more informal apprenticeship with a practising surgeon. ${ }^{61}$ Mere testimonial support of other surgeons was also accepted as proof of competence. At least twenty licences were awarded to aspiring surgical practitioners who provided statements signed by surgeons. These ranged from the one surgeon's signature provided by Gilbert Soper of St Martin-in-the-Fields to the four signatures supplied by John Kent of St Mary Whitechapel and Quaker Jonathan Christmas of Sudbury, Suffolk. ${ }^{62}$ Half a dozen applicants took the precaution of presenting supporting evidence from physicians (who were at the top of the medical hierarchy) as well as surgeons. The testimonial of John Firman, a gentleman from Colchester, Essex, bore the signatures of two surgeons and two physicians; one of the physicians' signatures was that of the eminent Charles Goodall. ${ }^{63}$

Another route taken by prospective surgeon-licensees was service in his majesty's navy or on privately owned ships such as those of the East India Company. By an Act of 1629, no ship's surgeon could leave the Port of London until his instruments and surgeon's chest had been examined by two officials of the Barber-Surgeons Company, but this did not ensure that all sea surgeons had served their apprenticeships with Company members. ${ }^{64}$ It was possible for a surgeon's apprentice who had completed approximately half of his apprenticeship to be accepted as a ship's surgeon, particularly in war time when demand exceeded supply. ${ }^{65}$ In 1690 orders were issued to "press 40 surgeons mates for the King's service in Ireland" with no indication of minimal qualifications (if any). ${ }^{66}$ Three surgeons pronounced William Tyreman "fit and capable to practice as a licensed chirurgeon" in 1670 because he had served at sea under Sir Jeremie Smith with "integrity and skill", while three surgeon's mates used their experience at sea to support their successful applications for surgeons' licences in $1697 .{ }^{67}$

Aside from the surgeons who were able to present evidence of some type of "official" training and experience, there were applicants with more tenuous claims to expertise in their field. Francis Seymour of New Brentford "did learn the Art of Chirurgery of his master John Gisby" of New Brentford who was a medical doctor. ${ }^{68}$ Thomas Ridout, licensed in the early 1660s, produced the signatures of five males, apparently with no

\footnotetext{
${ }^{61}$ For examples of men who had trained with surgeons, apparently without an association with the Barber-Surgeons Company see GL MSS $10,116 / 13,14$.

62 GL MS 10,116/3, LP VX $1 \mathrm{~A} / 10 / 291$. It is unusual for a Quaker to receive an ecclesiastical licence, but, as was the case with an occasional midwife, an applicant might compromise his position on oath-taking. Harley, op. cit., note 2 above, pp. 407-8.

${ }^{63}$ GL MS 10,116/9.

64 Parker, op. cit., note 27 above, p. 118.

65 Forbes, op. cit., note 22 above, pp. 229, 233.

66 Young, op. cit., note 7 above, p. 220.

${ }^{67}$ GL MS 10,116/7/14, LP VX 1A/10/337.
}

Service as an army surgeon was also cited in support of an application for an ecclesiastical licence. Francis
DeLaze, a Huguenot surgeon who had completed his apprenticeship in France, served as a surgeon to Col. Mackay's regiment in Scotland and Flanders for three years. GL MS 10,116/13. See GL MS

$10,116 / 14$ for two other applicants (Nicholas Lawless and John Browne) who cited military service in their testimonials.

${ }^{68} \mathrm{Six}$ other successful candidates for a licence in surgery received their backing from physicians who were willing to vouch for their competence in carrying out surgical procedures. GL MS 10,116/3, 6, 13,14 . Only two men sought testimonial support from apothecaries. John Drinkwater of New Brentford included the testimony of a surgeon and apothecary in 1697, while Joseph Freeman of Little Waltham, licensed in 1692, obtained the signatures of two apothecaries, GL MS 10,116/13,14. 


\section{Licensing and Practice of Female and Male Surgeons}

connection to matters medical, who noted that he had "some skill in letting of blood and drawing teeth and performing some other Arte of chirugery". ${ }^{9}$ Approximately a dozen successful candidates lacked any visible support from medical or surgical practitioners, with testimonials signed by varying numbers and combinations of clergy and male acquaintances. Noting that he had "done many good cures" to the poor as well as the rich, James Vaughan of Epping obtained his curate's signature and the signatures of fourteen males of unknown status who may have been former patients. ${ }^{70}$

The ambiguity surrounding standards for obtaining an ecclesiastical licence to practise surgery was further compounded by the licensing of individuals as both surgeons and physicians. At least sixteen licences were issued by the Bishop of London in the first three decades after the Restoration which confirmed the recipient in the double role of physician and surgeon. In the 1690s, the Archbishop of Canterbury conferred the double designation on forty-one practitioners making it the licence of preference for Lambeth recipients. Once again the testimonials were signed by a variety of practitioners and laymen. ${ }^{71}$ Charles Willcox had supplemented his experience as Master of the pesthouse in Tower Hamlet with an appointment as surgeon to "his majesties' Royal garrison"; his testimonial certificate of 1669 made the somewhat large claim that he was "of ability and knowledge in physice against all diseases incident to man, woeman and children [sic]". Lionel Lockyer, "licensed physician", and several other physicians supported Willcox who was licensed as a physician and surgeon. ${ }^{72}$ The occasional licence was granted upon the testimony of lay-persons alone. Such was the case in 1693 when Robert Colwell, a gentleman with a bachelor's degree from Oxford, was licensed to practise medicine and surgery. ${ }^{73}$ Nathaniel Moore of Terling, Essex, licensed in 1691, relied exclusively on clerical testimony from three different parishes. ${ }^{74}$

When examining testimonial evidence for male practitioners, one is struck by several conclusions. The first is the pervasive presence of professional support for the applicants; this is true whether the candidate had served a formal apprenticeship or not. ${ }^{75}$ Secondly, one notes the open-ended mandate which male practitioners acquired to unrestricted practise across the whole spectrum of surgery, physick, or both, with minimal training or qualifications. Finally, in many cases, we find that very little attention was paid, in these male applications and testimonials, to patients' opinions about prospective licensees. ${ }^{76}$

${ }^{69}$ GL MS 10,116/3. Both blood-letting and toothpulling were tasks of barbers.

70 GL MS 10,116/8.

${ }^{71}$ In his study of provincial physicians, Harley has also noted the great diversity in requirements for obtaining an ecclesiastical licence. Harley, op. cit., note 2 above, p. 400.

72 GL MS 10,116/6. Lockyer has been described as a "quack" who gained a reputation by virtue of pills which bore his name and were claimed to be a "universal" cure. See Hector A Colwell, 'Lionel Lockyer', Proc. R. Soc. Med., 1915, 3: 126-34. No confirmation of his licensing by ecclesiastical authorities has been found suggesting the claim to it was fictitious, but the Church accepted his endorsement of a candidate for a medical licence in 1661. See J K Crellin and J R Scott, 'Lionel Lockyer and his pills', Proceedings of the 23rd International
Congress of the History of Medicine, London, Wellcome Institute for the History of Medicine, 1974, vol. 2, 1182-5, p. 1184.

73 The supporting signatures were added by curate Andrew Colwell, obviously a relative, two vicars, two yeomen, a butcher and another unidentified male. LP MS VX 1A/10/276.

${ }^{74}$ GL MS 10,116/13.

75 Evidence from ecclesiastical archives is at odds with Bloom and James who argued that only those who had "a long course of apprenticeship to a recognised medical man ... and proved by their own practice ..." stood much of a chance of getting a licence. Bloom and James, op. cit., note 6 above, p. 9.

${ }^{76}$ Excluding the patient's view from medical history has been criticized by historians. See Roy Porter (ed.), Patients and practitioners: lay perceptions of medicine in pre-industrial society, 


\section{Doreen A Evenden}

John Raach has speculated that the standards imposed for ecclesiastical licensing were hazy and that the chief qualification was the practitioner's ability to effect cures. ${ }^{77}$ In the documents presented to the Church courts of London and Canterbury, however, testimony of other practitioners, no matter how casual the association may have been, was accepted without, in most cases, any reference to successfully completed cures. ${ }^{78}$

William Preston's testimonial noted that in his six years of practice he had had several cures of individuals "very desperately diseased", while four or five other testimonials referred somewhat obliquely to successful "cures" of unnamed patients. ${ }^{79}$ The testimonial of Nicholas Cambridge of St Giles-in-the-Fields affords a rare glimpse into the type of service provided by a male practitioner, trained by practical experience, who sought a licence in surgery. We are given the names of a few patients, and, in some cases, their actual statements. Cambridge "cured" John Whigston's fractured leg (personally attested), and Mary Collins "being dangerously bitten by a mastiffe having many lacerated wounds"; he also successfully treated R_ "which was bit with a dog about a 100 holes". Thomas Mason vouched for the cure of his maid's leg, while Robert Dagley, Thomas Greenfield and Thomas Sanders swore to the "cures" of their respective ailing hands, legs, heads and arms. ${ }^{80}$ This testimonial stands out as virtually the only one to provide this type of information. An examination, therefore, of surviving testimonial certificates from the seventeenth century leads to the conclusion that for an ecclesiastical licence to practise surgery or medicine and surgery, very little proof of actual skill in terms of successful "cures" was needed, at least for male candidates. The picture will change when we turn to female practitioners.

\section{Licensing of Female Practitioners}

The records of the Archbishop of Canterbury have yielded the names of seven women who were licensed in surgery. Three of these were outside the London area, but information on all surviving testimonial certificates sheds a great deal of light on the position of licensed women surgeons of the period. Early in the seventeenth century, the registers of Archbishop Abbot (1611-33) record the licensing of two female surgeons, Eleanor Woodhouse of St Leonard Shoreditch (1613) and Anne Hubbard of Toft Monks, Suffolk (1615). No details of their practices survive in the form of testimonial certificates but we know that they were not widows and that Woodhouse was married to a vintner,

Cambridge University Press, 1985; Dorothy Porter and Roy Porter, Patient's progress: doctors and doctoring in eighteenth-century England, Stanford University Press, 1989, p. 13 ; Beier, op. cit., note 52 above, p. 7.

${ }^{77}$ Raach, 'Licensing', op. cit., note 5 above, p. 280. Although loss of documents is always a possibility, it would be difficult to accept that testimonial evidence of "cures" had been lost for all of more than 160 male candidates and preserved for only the handful of female candidates.

78 Roberts has also noted the laxity of church officials which enabled incompetent practitioners to obtain licences in surgery. Roberts, op. cit., note 22 above, p. 220. This stands in direct contrast to the Church's policy on the licensing of midwives where the testimony of satisfied clients was required. See Evenden-Nagy, op. cit., note 54 above, ch. 1, 'Ecclesiastical licensing of midwives', passim.

${ }^{79}$ GL MS 10,116/2. See also James Vaughan, Theophilus Aylmer, Thomas Newman, GL MS 10,116/8,10,14; Robert Colwell, Thomas Silvester LP MS VX 1A/10/276, 312.

${ }^{80}$ GL MS 10,116/8. Although Cambridge's testimonial was signed by a surgeon and two churchwardens, there is no indication of formal training. This suggests that he was entirely selftaught. 


\section{Licensing and Practice of Female and Male Surgeons}

indicating that she was licensed on her own ability as a surgeon. ${ }^{81}$ Woodhouse was probably the "Mrs. Woodhowse" who had run afoul of the College of Physicians in 1602 but had been spared prosecution by the intercession of a highly placed member of the government who had employed her services to treat a family member. ${ }^{82}$ Some years later Isobell Davis, also married, who lived on Gravel Lane near Aldgate, was licensed as a surgeon. The entry indicated that her practice was limited to using her skill in "curing Sore breasts and other infirmities of women" and added that she required "noe fees for her paynes, but freely leaving it to every one to gratifie her as they see good and doeing it gratis to ye Poore". 83 Davis was a "specialist" in treating women who would pose no threat to male surgeons either in terms of fees or specialization.

In the last decade and a half of the century two women were licensed as surgeons, two as physicians and surgeons, and one as a midwife and surgeon. Their documentation affords some remarkable insights into the practice of female surgeons as well as into the licensing requirements of the period. The testimonial of Elizabeth Wheatland of Winchester contained the statement of five men and one woman that she was skilful in the art of surgery, a skill from which they had benefited. ${ }^{84}$ A second document was signed by three men who had "examined" her, one of whom identified himself as a physician and surgeon. The three also stated that not only was she "fitly qualified as a surgeon" but also an "expert in boansetting". Evidently Dr Sherlocke "of the Temple" had personally spoken to the vicar general, Thomas Penfold, on behalf of the applicant. ${ }^{85}$ Wheatland was licensed to practise surgery in the dioceses of Winchester and Salisbury in 1687.

A few years later, the Bishop of London issued a licence for the practice of surgery to a female candidate. She was Elizabeth Francis who was licensed in 1690 to practise surgery and obstetrics. It is clear from the supporting statement, signed by two physicians (one of them from the Chamberlen family of "forceps" fame), a surgeon and a male midwife, that the expectation was that her practice would be limited to women. It reads in part:

having examined Mrs. Elizabeth Francis I find her to be very well instructed and practiced in the art of midwifery and also in the knowledge of medicines which may be of use to women in their several maladies. ${ }^{86}$

In the same year widow Elizabeth Moore of Market Harborrow, Leicestershire, was licensed by the Archbishop of Canterbury to practise medicine and surgery in the dioceses of Lincoln, Peterborough, and Coventry and Lichfield. ${ }^{87}$ Moore's testimonial bears the usual clerical signatures but it also contains the names (and, in some cases marks or signatures) of thirty-three patients who claim to have been cured by Mrs Moore (see Appendix A). The document describes the illnesses of twelve men, ten women and eleven children. Ten of the thirty-three cures were for scrofula or the King's Evil. In two of these cases, it was claimed that the patients were "blind" as the result of the disease while a third

${ }^{81}$ LP MS Abbot 1, fols. 170v, 169v-70.

82 Wyman, op. cit., note 10 above, p. 29.

${ }^{83}$ LP Acts Book VB1/1/3.

${ }^{84}$ LP VX 1A/10/247.

85 Dr Sherlocke was William Sherlock, dean of St Paul's and Master of the Temple (chief minister of

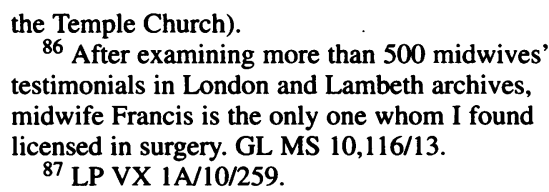




\section{Doreen A Evenden}

had fistulas in her face and running sores on her hands and arms. ${ }^{88}$ Six patients were treated for a variety of fevers, while three were cured of lameness. Two cases each of "surfitt", rickets and "impostumes [abscesses] in the stomach" were successfully treated. ${ }^{89}$ Other cures were claimed for consumption, smallpox, "rupture on the lung", palsy of the tongue, toothache, mental derangement (three times in the same woman) and a "dangerous sore throat" in a post-partum female.

It appears that a relative of widow Moore, one Thomas Moore (her son?), drafted the document. ${ }^{90}$ Thomas also included his own statement noting her success in the "cures of Agues, Feavers, small pox, Measles, Toothach and more espeacially the Kings-Evill ...". Thomas West, who signed with his mark, attested that he had been cured of two fevers and several other illnesses by Mrs Moore and had "made use of no other physician for 25 or 26 years". Mistress Moore treated a number of inhabitants in her own town of Market Harborough but the bulk of her practice was drawn from neighbouring towns lying within a ten mile radius of her home. In addition she treated several patients living some 40 miles to the north at Farndon, 38 miles to the south-east at Lidlington, and 20 miles to the southwest at Napton on the Hill. ${ }^{91}$ There is no indication of whether the patients travelled to Moore or she went to her patients; since many of the illnesses were chronic there is a good chance that they came to her. In some cases, they probably lived with her while undergoing treatment as they did with Elizabeth Penell (see p. 210 below). ${ }^{92}$

The testimonial of Mary Rose of Portsmouth was endorsed by seventeen women and twenty-five men in 1696 who signed a statement indicating that she had been successful in treating patients with conditions which demanded, in some cases, the services of a physician, as well as ailments which required treatment by a surgeon. In addition she was supported by the commanders and captains of two naval ships (one of them the Merlyn) and two ship's surgeons. Mistress Rose had undoubtedly been in attendance at the sick bed of seamen who were convalescing in the town of Portsmouth and thereby earned the respect of both medical and commanding naval personnel. ${ }^{93} \mathrm{~A}$ third surgeon, W Clemen, as well as London surgeon David Rose and medical doctor Philip Rose added their testimonies; Mary Rose was a woman with a strong family background in medicine.

\footnotetext{
${ }^{88}$ Scrofula or the King's evil was the name given to chronically inflamed glands, usually associated with the tubercle bacillus, and believed to be curable by the touch of the Queen or King. Some of the cases treated by Moore, however, were probably the result of other chronic infections including osteomyelitis and eye infections.

${ }^{89}$ Surfitt or surfeit was the name given to illness believed to result from excessive indulgence in food or drink.

${ }^{90}$ For "official" documents of this nature, most ordinary people would pay to have a scribe draft their remarks. Therefore, the fact that a relative acted as scribe in no way invalidates the claims but reflects somewhat positively on Moore's social status. The Edward Moore whose signature appeared on the first page was also probably a close relative who lived in the nearby village of Slawston.

${ }^{91}$ By way of comparison, the records of a provincial doctor who practised early in the century
}

in Yorkshire reveal much the same patterns of distribution; none of his patients, however, were found at more than a distance of twenty-five miles. See W R Le Fanu, 'A North-Riding doctor in 1609', Med. Hist., 1961, 5: 178-88.

92 For examples of patients residing with their surgeon, see Hunter and MacAlpine, op. cit., note 52 above, p. 44. For other examples of the way in which provincial doctors carried out their practices within the constraints of distance and time see Evenden Nagy, op. cit., note 3 above, pp. 4-19.

${ }^{9}$ See Doreen Evenden, 'Mary Rose a seventeenth-century Portsmouth surgeon', Mariner's Mirror, 1993, 79: 33-4. For comment on the practice of putting ailing seamen ashore for treatment and convalescence see J D Alsop, 'Sea surgeons, health and England's maritime expansion: the West African trade 1553-1660', Mariner's Mirror, 1990, 76:

215-21, p. 220. 


\section{Licensing and Practice of Female and Male Surgeons}

Moreover, she signed her oath in her own clear and graceful "hand" using the Latin spelling of Mary (Maria). ${ }^{94}$ Despite Mistress Rose's support from townspeople, naval medical personnel, and other professionals, the recording clerk noted that her medical and surgical practice would be limited to the treatment of certain (unspecified) areas of medicine and surgery.

The female surgeon who has left the fullest documentation of her life and practice is Elizabeth Penell or Pemell whose testimonial is a virtual case record of at least part of the practice of this resident of St Salvatore parish, Southwark, who applied for a licence to practise surgery in 1685 and was subsequently licensed in surgery by Sancroft, Archbishop of Canterbury, throughout the province of Canterbury. ${ }^{95}$ It is comprised of sheets of vellum folded and stitched together to form a booklet of twelve folios. Mistress Penell "specialized" in the treatment of "scrofulus humouris comonely called the King's Evill \& nolime tangere [touch me not]" and she presents the names of sixty-six men, women and children whom she has successfully treated for these afflictions. ${ }^{96}$ In several instances, graphic descriptions are given of the appalling symptoms from which these patients suffered :

Ane Cariller[s] daughter in Harrow Alley who had it in her bake, thighes \& both feet, both hands and fingers 24 running sores at one tyme and blinde in her Eies and pints of Corruption hath rune out of the sores at one tyme and had a perfect cure. [witnessed by] Elizabeth Wiggs and John Danford.

Mrs. Hill at the Whit Bare in Southwark her daughter being blind \& the Eie starting out of her head like a ball of blood, ...

Mr. Empsons kinswoman at the Fyery Beakon in Dukes Place shee had it at ye side of her belly next to her bowells, severl sores in her neck \& hands \& feet and several bones came out.

Mr. Walker a porter to the speaker in parliament living the next doore to the Palsgrove head without Temple barr his sone his whole chine came off with the mayne bone teeth \& all, with a nolemitangere, and it hath pleased god to send him a chine againe. [signed with] The mark of Susan Walker his mother.

Elizabeth Penell's patients were drawn from a broad social spectrum. Among the adults she treated were a book-seller, King's sword cutler, instrument maker, ribbon weaver,

\footnotetext{
${ }^{94}$ Both the quality of the handwriting and the use of the Latin form of her name are indications of her educational attainments. Although male candidates, especially those who were university graduates, frequently Latinized their first names, as did clerks who recorded women's licensing information for midwifery (or, occasionally, surgery) in the bishop's registers, this is the first time I have found a woman who Latinized her own name. I suspect also that she had nonconformist leanings since a separate oath of conformity, a full page in length, was demanded by the Church court at the time of her licensing as a physician and surgeon in the province of Canterbury. LP VX 1A/10/297. The oath was very strongly anticatholic. Perhaps the Rose family with their French name were suspected of recusancy. My research with London records indicate that Huguenot applicants to
}

ecclesiastical courts appeared to make a special effort to disclaim any link with Catholicism. For other examples of nonconformist practitioners who obtained ecclesiastical licences see Harley, op. cit., note 2 above, pp. 407-9.

${ }^{95}$ LP VX $1 \mathrm{~A} / 10 / 223$.

96 Noli me tangere is described as "any of several ulcerous cutaneous diseases of the face, especially lupus and rodent ulcer" (SOED). It is difficult to tell from the context whether or not Penell recognized the latter as a completely separate disease or a variety of scrofula. As was the case with Elizabeth Moore, some of the conditions would not have been tuberculous in origin, but rather the result of other chronic (secondary) infections lumped together under the catch-all diagnosis of scrofula or King's evil. 


\section{Doreen A Evenden}

porter, poulterer, baker, and at least three servants. From the titled aristocracy and gentry: two children, two grandchildren and a niece. Merchants were among the wealthiest inhabitants of seventeenth-century London, but these unpleasant, chronic afflictions were no respecter of social class or income; the children and relatives of ten merchants were patients of Mrs Penell. ${ }^{97}$ In addition to the two adults who were engaged in food handling for their livelihoods, the offspring of a cheesemonger, butcher, baker, and wholesale grocer were treated for a variety of unappetizing symptoms.

Among the most interesting cases that surgeon Penell recounts are those of patients who had been unsuccessfully treated in hospital. About Bartholomew Harris she says: "he was in Bartholomews Hospital and could have noe cure, his Arme to bee cut off, I prayse god I cured him." She further notes that Harris "hath since married with one of the sisters of the sayd Hospital", and Bartholomew Harris himself has witnessed to the authenticity of her statements. Another patient who failed to be cured at St Bartholomew's, Abraham Simpson, "who had it in his thigh \& several bones came out", was successfully treated by Penell. Christ Church Hospital was unable to cure either Master Hall or Joseph Tyler; Penell notes of the foregoing four: "those came all out of the Hospitall to me, in a small lyne after each other \& I prayse god they have all had their cure." She adds that she has also treated patients from St Thomas's hospital, but adds with becoming modesty, "I shall forbear mentioning any more being all ready tegious [tedious]."

Mistress Penell gave not only the occupations of her patients or their families, she also, in many cases recorded their addresses. We know, therefore, that she did not confine her practice to a substantial representation in her home area of Southwark but travelled into the City of London and well beyond its walls in the course of her work. In the western suburbs she treated patients at Charing Cross and Lincoln's Fields. She travelled as far north as Shoreditch, but it was in the east that she located the greatest number of her patients in the overcrowded confines of Harrow Alley, the Minories, Houndsditch and Whitechapel. ${ }^{98}$ Penell's reputation as a healer had attracted a patient from the country thirty miles away who was currently living with her: a "little child . . . [who] had above a hundred holes about her, her lip, eare a[1]most a Sunder with it and corruption purging out of her nose". Penell added that she had witnesses who had seen the child in this pathetic condition and who could testify that she was now "perfectly well".

It is unfortunate that we are given few details of the actual treatments that Elizabeth Penell administered. In one case, that of a four inch lesion of the neck, the treatment consisted of drainage. She mentions removing the "bagg" after the "soar" had gathered five times; subsequently, the neck was healed. In two cases she successfully removed lumps or "wenns", as she calls them, but there is no indication of whether they were excised or treated more conservatively. Her most interesting comments disclose how she

\footnotetext{
${ }^{97}$ For comment on the relative prosperity of merchants see $\mathbf{M} \mathbf{J}$ Power, 'The social topography of Restoration London', in Beier and Finlay, op. cit., note 3 above, pp. 199-223, on pp. 213-14.

${ }^{98}$ Midwives who practised in the City of London in the seventeenth century also ranged over a wide geographic area. See Evenden-Nagy, op. cit., note 54 above, pp. 171-5. The parishes of St Botolph Aldgate and St Botolph Bishopsgate where Penell's
}

practice was concentrated were densely populated and poverty-stricken for much of the period. See Ronald W Herlan, 'Social articulation and the configuration of parochial poverty in London on the eve of the Restoration', Guildhall Stud. Lond. Hist., 1976, 1: 43-53, and idem, 'Poor relief in London during the English Revolution', J. Br. Stud. 1979, 15: pp. 30-51. 


\section{Licensing and Practice of Female and Male Surgeons}

treated a Captain Hasting's son of Ratcliffe Cross who had previously been treated by surgeons. The surgeons had placed a lead plug in the boy's back to allow unhealthy humours to escape. Evidently it had become infected and had continued to drain over a long period of time. Penell describes how she "pikkt it out and serringed it with a watter which went through his body \& by god's blessing cured it". Despite her extraordinary success as a healer, Mistress Penell felt compelled to substantiate her qualifications further. She describes how her first husband had been a physician and male midwife; her second husband, Henry Tyrell, and her father-in-law had both been surgeons, the latter at Christ Church Hospital; her third husband, John Penell, was taken captive in the Dutch wars "and lost all he had goten in Seven yeares"; previously, the couple had left the City after being burned out in the Great Fire. ${ }^{99}$ Mistress Penell concludes her biography with a plea for a licence that would enable an "honest mayntenance" for the aging couple in the work which she had so successfully carried on for "about twenty years". Penell's family background and her own empirical experience begs the question as to why this woman would go to the trouble of acquiring a licence? In her own words, she seeks a licence in order to earn an "honest" living in a period when the approval of the medical establishment was more freely bestowed upon women who ministered to the sick out of charity and posed no threat to their pocketbooks. ${ }^{100}$ Perhaps she could charge a more competitive fee if licensed; perhaps she had been harassed by a neighbouring male practitioner who boasted a licence. ${ }^{101}$ Finally, the threat of presentation at an ecclesiastical court for unlicensed practice, posed by an unusually zealous churchwarden or other parish official, might have prompted her quest for official standing at this time.

\section{The Role of Gender in Licensing}

If we use the example of seventeenth-century London, it is difficult to avoid the conclusion that for women a surgical practice which was legitimized by a licence was extremely rare. ${ }^{102}$ Ecclesiastical licences were granted occasionally but these were

\footnotetext{
99 Penell was referring to the "third Dutch War" which was fought between the Netherlands and England and her French allies, which saw England defeated in 1672. Since Penell states that she has been practising for twenty years, she must have begun after her move to Southwark.

${ }^{100}$ Evenden Nagy, op. cit., note 3 above, pp. 73, 76. Although critical of women who practised surgery without theoretical knowledge, Richard Banister approved of two women, one an aristocrat, who treated the poor out of charity. Banister, op. cit., note 39 above, 'Forward'. Another treatise published by four surgeons from St Bartholomew's Hospital and incorporating the work of sixteenth-century royal surgeon Vicary states that it is intended for "Gentlewomen and others who desire Science in Medicine and Surgery for a generall good". It subsequently makes clear that they will be treating the needy in the "remote parts of this Kingdome" and will be acting out of charity. Thomas Vicary, The surgion's directorie, for young practitioners, in anatomie, wounds and cures \&c., London, 1651, Part VIII.
}

\author{
${ }^{101}$ Male medical practitioners were able to \\ command substantial fees in some instances. See \\ Evenden Nagy, op. cit., note 3 above; Earle, op. cit., \\ note 18 above, pp. 132-3; Harley, op. cit., note 2 \\ above, p. 406. In the case of London midwives, the \\ women themselves tried to ensure that, in accordance \\ with their oath, only duly licensed midwives \\ practised in the city. There is no question that a \\ licence in midwifery was seen as the important end \\ result of the unofficial system of apprenticeship \\ which existed throughout the seventeenth century. \\ Evenden-Nagy, op. cit., note 54 above, pp. 92-3. \\ 102 Peter Earle, in his recent discussion of \\ seventeenth-century London women's work, \\ concluded that it was unlikely that many women \\ engaged in medical practice would have taken the \\ trouble to apply for a licence since they would \\ probably have been refused. Earle, op. cit., note 18 \\ above, p. 132. A study of Norwich practitioners in \\ the sixteenth century found no dearth of unlicensed \\ female medical practice but only one licensed female \\ surgeon. See Pelling and Webster, op. cit., note 10
}




\section{Doreen A Evenden}

extended in what can only be described as exceptional circumstances: a family connection to male practitioners in surgery and/or physick, as well as an understanding that the woman's practice would be limited to certain specialties 'such as female "complaints", bone setting, or distasteful, chronic ailments requiring prolonged treatment for which many sufferers could not afford substantial payment, if any at all. ${ }^{103}$ In three cases licences were granted to practitioners working far beyond the areas jealously guarded by London medical monopolies thereby removing any possible threat of competition to male practitioners. Elizabeth Moore and Elizabeth Penell met the criteria of a "specialist" in the treatment of scrofula, which surgeons no longer wished to treat, while Elizabeth Wheatland excelled in bone setting. Mary Rose of Portsmouth had family medical connections, and had the support of highly placed naval officers who attested the valuable service that she was performing for naval personnel; even so the ecclesiastical authorities placed limitations on the medical and surgical treatments she could carry out. All four women who were licensed to practise surgery, or surgery and physick had unusual life experiences, skills and personal circumstances which enabled them to overcome the traditional barriers to female surgical practice, but they were rare exceptions in the seventeenth century. We do not know how many women sought ecclesiastical licences for the practice of surgery and medicine in the seventeenth century, nor why, except in Penell's case, they were moved to seek licences. ${ }^{104}$

After examining hundreds of testimonial certificates, the conclusion emerges that gender was a factor which influenced the application process itself. Males who applied for ecclesiastical licences were not expected to provide the type of documentation which women presented. ${ }^{105}$ The question of whether licensing was a privilege or an imposition is, in the main, irrelevant; it was a barrier which prevented women from standing on an equal footing with their male counterparts. ${ }^{106}$ In the case of female surgeons we have no way of knowing whether the demands which compelled Elizabeth Penell and Elizabeth Moore to compile such extraordinary records of their practice to accompany their testimonial certificates were explicit or implicit. They may have been influenced by the

above, p. 233. Similarly, Margaret Barnet's study of York barber-surgeons documents one licensed female in the early modern period. Barnet, op. cit., note 7 above, p. 27. There is also the case of the poor girl who was apprenticed to a "surgeoness" from St Leonard Shoreditch in 1729. Wyman, op. cit., note 10 above, p. 30 , but such an occupational designation has not been linked with either the Barber-Surgeons Company or the ecclesiastical licensing process. I suspect that this was a private arrangement between the "surgeoness", Anne Saint, and parish officials and that she was treating conditions like scald head (ringworm of the scalp) for which treatment women were regularly employed. See Pelling and Webster, op. cit., note 10 above, pp. 223-4; Margaret Pelling, 'Healing the sick poor: social policy and disability in Norwich 1550-1640', Med. Hist., 1985, 29: 115-137, pp. 128-9; Barnet, ibid., p. 25. See also Willen, op. cit., note 10 above.

${ }^{103}$ As an example of the types of treatment surgeons tried to avoid, in 1656 regulations for the government of St Bartholomew's Hospital noted that while the staff would include two surgeons, "a woman" would be paid from 20 s to 40 s "the cure" to treat scald head (ringworm) and leprosy. Calendar of State Papers: domestic series, Commonwealth, vol. 9, 1656, p. 23.

${ }^{104}$ After examining hundreds of testimonial documents, it is apparent that testimonials were kept for successful candidates only. There is no way of telling if other women had applied unsuccessfully.

105 This is also true of midwives who applied for licences and were required to provide much more substantial documentation than candidates for licences in medicine or surgery. See Evenden-Nagy, op. cit., note 54 above, ch. 1 , 'Ecclesiastical licensing of midwives', passim.

106 In the case of London midwives, the overwhelming evidence points to the conclusion that licensing was an imposition which conferred privilege and standing. I suspect, but have less proof, that this was the case with female surgeons and surgeon/physicians. 


\section{Licensing and Practice of Female and Male Surgeons}

requirements that the Church had created for the licensing of midwives, for example. ${ }^{107}$ Surviving evidence, however, suggests that then, as now, women who wished to succeed in professions or occupations traditionally perceived as "male" had to prove that they were exceptionally well qualified in order to obtain something like equal recognition. That being the case, Mary Rose, Jane Penell, Mrs Moore and the other female licensees deserve recognition as particularly dedicated and able women who overcame the not inconsiderable handicaps which they faced. ${ }^{108}$

It is difficult to remain detached from twentieth-century perceptions of the way in which gender has influenced the composition of the medical profession, but an examination of seventeenth-century records has demonstrated that the number of women who gained admission to the ranks of accredited surgeons was consistently minuscule and that gender and, by extension, education, were key factors in their exclusion. ${ }^{109}$ Although not underestimating the contribution of countless unlicensed female practitioners to health care in the early modern period, this study casts some light on why they remained largely unlicensed and therefore unrecorded. ${ }^{110}$

\footnotetext{
107 Seventeenth-century London midwives were expected to have six women (usually clients) to give sworn testimony before the ecclesiastical licensing authorities that they had personal knowledge of the midwife's expertise. Evenden-Nagy, op. cit., note 54 above, chs 1 and 2, passim.

108 See Peter Earle, 'The female labour market in London in the late seventeenth and early eighteenth centuries', Econ. Hist. Rev., 2nd ser., 1989, XLII, 3: $328-53$, p. 346. Earle discusses the way in which the distinction between "men's work" and "women's work" severely restricted working women's options for employment in the period.

${ }^{109}$ Harley, op. cit., note 2 above, p. 398. While Harley adds religion to the exclusionary factors, because this study deals with records of successful
}

applicants, no evidence was found of women, other than Mary Rose, who may have been confronted with religious barriers when applying for ecclesiastical licences. For a comment on the Church's increasing disinterest in the licensing process see Guy, op. cit., note 59 above, p. 537.

110 See Pelling and Webster, op. cit., note 10 above, pp. 222-5; Pelling, op. cit., note 19 above, pp. 487, 507-9; Evenden Nagy, op. cit., note 3 above, ch. 5, 'Women's role in Stuart medicine', pp. 54-78. In his recent study of London inhabitants, based on information from court depositions, Peter Earle has found one woman who claimed to be a surgeon and another who practised "surgery and physick", but, evidently, they were unlicensed. Earle, op. cit., note 18 above, p. 132. 


\section{Doreen A Evenden}

\section{APPENDIX A}

\section{Transcription of the testimonial certificate of Elizabeth Moore}

Source: Lambeth Palace Library MS VX 1A/10/259 (transcribed by D Evenden).

We whose names are here subscribed do certify that we know Mrs. Elizabeth Moore of Market Harborrow in the County of Leicester widow, to be a person of good skill in physick \& Chirurgery $\&$ very fit (in our opinion) to practise them and that we have known the good effects of her skill upon several persons.

December 281689

Edw. Moore Slawston [?] Richard Mowsse Rector of Bowdon parish Isaac Laughton M.A. John Howard Rector of Marston Trussell

We whose names are subscribed do certify that we have received much benefit by what Mrs. Moore hath administerd to us in several distempers-

Richard Jordon cured for lameness for which he could not go in a quarter of a year. (一) Rich: Jordan his mark.

My wife cured of the Evell and my soon of the small poox by Mrs. More this I will witne[ess] Ed: Wright of Farndon

I Henry Clarke of Mars[t]on doe certifie that one of my children was cured by Mrs. Moore of heirburow

The mark of Anne (-) Satchwel who was cured by Mrs. Moore of the Tooth ach in so violent a manner y[that] she was almost disstracted.

Edward Sedgly at Sutton cured of ye Kings Evill ye fistula in his face. (一) Edw: Sedgly his mark. William Spencer of Braybrooke cured of a surfitt by Mistress Elizabeth Moore [signed] William Spencer

Cured Mary Bayes of a feavor severall times and swooning fits by Mistress Moore [signed] Mary Bayes

Robert Smith of a surfit cured by Ms Moor [signed] Robert Smith

My daughter Eliz. Bayes being sorely afflicted with the kings evill that shee was blinde by it was parfectly cured by mis. Moore. [signed] Mary Bayes

Thomas Bates of Nosely cured of a dangerous impostume in his stumach by Mistress Moore. [signed] Thos Bates 


\section{Licensing and Practice of Female and Male Surgeons}

The widdow Wakman of Harbrough [Harborow] was thrice distracted \& was cured by Ms Moore. The mark of Mary Wakman (一).

Mary the daughter of Joseph Manton of Ox[t]on, was cured of the Kings Evill [by] Mistress Moore

Mary the daughter of Tho: Freeman of Knaptoft [Napton on the Hill] who had been twice touched for the Evill \& was blind with it was cured by Mistress Moore. [signed] Tho: Freeman.

Harbrough in Liecestershire Dec: 31-89.

I do know the within Ms. Moore to be a person of great skill and experience in the practice of physick, very safe in her administrations, \& very successfull in the cures of Agues, feavors, small pox, measles, toothach, \& more espeacially the Kings Evill with other diseases incident to the country. And one whome I have oftten received much good, in my severall sicknesses. In Testimony hereof, I do freely subscribe my hand. [signed] Tho: Moore.

Nicholas Clark of Bowden Magna, was cured of a dangerous Impostume in his stomach, and his son of the Ricketts by Mistress Moore.

Mistress Mary Clark of West Langton was cured of a plurisie \& violent feaver by Mistress Moore. [signed] Mary Clarke

A son of Madam Wykes of Hasselbich [Haselbech] cured of the Rickets by Mistress Moore

Wm Hill of Caldecot[t] cured of a consumption by Mistress Moore. [signed] Willm Hill

Thomas Furburrough of Throlesworth [?] cured of the palsy in his tongue, when he had lost his speech, by Mistress Moore. [signed] Thomas Furburrough

Amy Wells of Farndon cured of a Hectick feavor by Mistress Moore. [signed] John Wells

Mary the wife of Samuel Sturges of Lubenham, had so bad a sore legg, that she could neither go nor stand, for 14 months was perfectly cured thereof in three moneths, by Mistress Moore. [signed] Samuel Sturges

Thomas Berridge of Wilbars[t]ton was so sorely afflicted with the Kings-Evill, that he was blind \& disinabled to follow his calling for above a year, was perfectly cured thereof by Mistress Moore [the mark of ?] Thom Berridge.

The son of James Loake \& the daughter of the widdow Robinson, both of Ox[t]on, being both dangerously afflicted with Kings Evill, were perfectly cured thereof by Mistress Moore. [signed] James Moore

Grace Munton of Uppingham having the Evil fistulas in her face, \& nine running ulcers in her hands $\&$ arms, that she was a frightfull spectacle to behold, was perfectly cured thereof by Mistress Moore. [signed] Grace Munton

Tho: Warren of Liddington [Lidlington] cured of the Kings Evill by Mistress Moore \& Wm Warren his son struck with the palsey of which he was lame for half a year was cured by her also to admiration. witness my hand John Warrin the son of Thomas Warrin 


\section{Doreen A Evenden}

Eliz: Dunmer of Harbrough cured of a mallignent feavor, \& her daughter of a rupture upon her lungs by Mistress Moore The Mark of Eliz: (一) Dunmer.

Mary the wife of Johyn Pike of Harbrough was cured of a dangerous sore throat in her Lying in by Mistress Moore. The mark of Mary (-) Pike.

John West of Harbrough was cured of two feavors \& several other distempers by Mistress Moore \& has made use of no other physician for 25 or 26 years but the said Mistress Moore \& with good success. God be praised. The mark of John (-) West. 